\title{
GAWE VAN DIE LEWENDE GOD: DIE NAGMAAL IN TRINITARIESE PERSPEKTIEF
}

\author{
F. van der Walt \\ J.J. van der Walt \\ Departement Diakoniologie \\ Potchefstroomse Universiteit vir Christelike Hoër Onderwys \\ POTCHEFSTROOM
}

\begin{abstract}
HOLY COMMUNION IN TRINITARLAN PERSPECTIVE

Christ is tnly present in the sacrament of Hoty Communion and this presence is a gift of the triune God. Christ's words of institution clearly point to his self-sacrifice, but his sacrifice must not be isolated from the fact that God the Father also sacrificed his Son for all of us. This sacrifice does not only reveal something about the Son, but also about the Father. In Holy Communion, the gift of the Holy Spirit is our comnunion with Christ. Scripture however also points to the Spirit's involvement in the sacrifice of Christ. Furthermore the Spirit works in our hearts, activating our sumender as an answer to Christ's self-surrender.
\end{abstract}

\section{DIE TEENWOORDIGHEID VAN CHRISTUS BY DIE NAGMAAL}

Die Here skenk ons in die Nagmaal gemeenskap met Christus "deur sy Gees, sodat ons met liggaam, gees en siel eén met Hom word. Die band ... van die vereniging is die Gees van Christus, waardeur ons verbind word, en as ' $t$ ware 'n kanaal waardeur alles wat Christus self is en wat $\mathrm{Hy}$ het, na ons gebring word." Alleen deur die Gees word bewerk "dat ons die hele Christus besit en blywend in ons het" (Calvyn,1931: 4,17,12).

Dat Christus deur sy Gees by die Nagmaal teenwoordig is, is 'n sleutelgedagte in die gereformeerde Nagmaalsleer. Die werklike teenwoordigheid van Christus by die Nagmaal staan hier sentraal. Christus se teenwoordigheid is nie geestelik en dan in die betekenis van minder werklik nie. Hy word ook nie vervang deur die teenwoordigheid van die Heilige Gees nie. In die uitdrukking deur dic Gees gaan dit vir Calvyn om die wyse waarop ons tussen Pinkster en die wederkoms met Christus gemeenskap het.

Deur sy Gees het hier dus heilshistories-trinitariese betekenis (Berkouwer, 1954:320) Christus se belofte dat daar ' $n$ "ander" Voorspraak sal kom (Joh 14:16), betcken nie dat die Heilige Gees Christus kom vervang nie, maar moet uit die heilshistoriese voortgang van Christus se werk verstaan word. Ná sy hemelvaart is Christus by sy kerk 
Die Nagmaal in trinitariese perspektief

Gees. Die verhoogde Christus woon en werk in sy gemeente "op de wijze van de Geest" (Versteeg, 1980:53).

Dit is die verhoogde Christus wat teenwoordig is by die Nagmaal en met Wie ons gemeenskap beoefen. Maar dit beteken nie dat Christus as die Gekruisigde hier op die agtergrond tree nie - inteendeel. Die gelowige het juis gemeenskap met die verheerlikte Christus, omdat hy gemeenskap het met sy liggaam en bloed (Berkouer, 1954:313). Die werklikheid van die verhoogde Here is nie los te maak of los te dink van die vernedering van Christus en van sy offer nie (Berkouer, 1954:319). Deur die sakrament en in die krag van die Heilige Gees verbind die verhoogde Christus die gemeente met Hom as die Een wat vir ons gekruisig is (Beker \& Hasselaar, 1987:182).

By die instelling van die Nagmaal wys Christus onmiskenbaar op sy offer.

\section{DIE SELFOORGAWE VAN DIE SEUN}

In sowel die brood- as bekerwoord gaan dit oor Christus in sy selfoorgawe aan die kruis. Versteeg (1980:43) parafraseer "dit is my liggaam" met "dit is Ekself in my selfoorgawe aan die kruis". Die bekerwoord "dit is my bloed" omskryf hy met "dit is Ekself in my geweldadige dood" (47). Christus het sy liggaam en daarin Homself vir ons oorgegee. Dit is juis hierdie moment, naamlik Homself weggee, wat die Nagmaal baie nadruklik vasle (Trimp, 1985:83). Christus het Homself in sy liefde eenmaal heeltemal vir ons gegee. Dit het so ver gegaan dat dit nie verder kon nie: Hy het Homself vir ons in die dood gegee (Trimp, 1985:8)). In die selfoorgawe sien ons sy hart.

Die spesifieke van die Nagmaalsviering is die gedagtenis aan die selfoorgawe van Christus. Op daardie moment hou die gelowiges die vergrootglas bokant die brandpunt van Christus se liefdeswerk: hulle let op die liggaam en bloed van Christus (Trimp, 1985:93).

Vir hierdie oorgawe van Christus gebruik Paulus die werkwoord rapa $\delta i \delta \omega \mu$ in die bekende Galasiërs 2:20, waar hy sê dat die Seun van God "my liefgehad het en Homself vir my oorgegee het". Die treffende is dat Paulus dieselfde woord gebruik om te sê dat die Vader sy eie Seun vir ons oorgegee het (Rom 8:32; kyk verder onder "Die gawe van die Vader"). Die selfoorgawe van die Seun staan dus nie op sy eie nie; ons het daarin ook met die oorgawe van die Vader te doen. Trouens, die selfoorgawe van die Seun is volgens die Skrif niks minder as die gawe van die drie-enige God nie. Vader en Heilige Gees is op ' $n$ besondere wyse betrokke by die selfoorgawe van die Seun. 


\section{DIE GAWE VAN DIE VADER}

Calvyn begin sy uiteensetting oor die Nagmaal in die Institusie met die beeld van die Vader, wat nadat Hy ons as sy kinders in sy huisgesin opgeneem het, ons ook versorg en voed $(4,17,1)$. Die Vader nooi ons na die Nagmaal $(4,17,1)$ en Christus is deur die Vader as brood van die lewe aan ons gegee $(4,17,4)$.

Op die agtergrond hiervan staan daardie gee uit die hart van die evangelie: "God het die wêreld so liefgehad dat Hy sy enigste Seun gegee het, sodat dié wat in Hom glo, nie verlore sal gaan nie, maar die ewige lewe sal hê" (Joh 3:16). Calvyn sê in sy kommentaar op hierdie vers dat die naam "eniggebore Seun" hier uitdruklik gebruik word om die geweldige liefde van God jeens ons te prys". Ons was vir God so dierbaar "dat Hy selfs sy eniggebore Seun om ons ontwil nie gespaar het nie".

Hieruit is al duidelik dat die gee van die Vader gee tot in die dood beteken. Dit word verder onderstreep as Paulus sê: "Hy het sy eie Seun nie gespaar nie, maar Hom oorgelewer om ons almal te red" (Rom 8:32). Paulus gebruik vir "oorgelewer" die werkwoord $\pi \propto p \alpha \delta i \delta \omega \mu$ wat dui op prysgegee word aan die mag van boosheid en lyding, "in het Nieuwe 'Testament een staande uitdrukking voor Christus' lijden en sterven" (Ridderbos, 1959:104). Dit is treffend dat Paulus dieselfde woord in Romeine 1 gebruik wanneer hy drie maal (vers 24,26 en 28 ) ná mekaar sê dat God die mense in hul sonde oorgegee het aan die gevolge daarvan. "Oorgelewer" in Romeine 8:32 het dus ook die betekenis van deur God in toorn oorgelewer en prysgegee as 'n sondaar. Ridderbos (1959:198) praat van 'n prysgee in menslike verlorenheid.

Hierdie "oorgelewer" sê nie net iets oor die Seun nie, maar ook oor die Vader. Smail $(1987: 124,125)$ sê dat geen Jood Romeine 8:32 kan lees sonder om te dink aan Abraham se offerande (Gen 22) nie. Ook Ridderbos (1959:198) sê dat die terminologie van Romeine 8:32 aan die offer van Abraham herinner. Volgens Genesis 22 het Abraham in droefheid gereed gemaak om Isak te offer. Maar in Romeine 8:32 sien ons die Vader van Jesus Christus wat nie hierdie keer tussenbeide tree nie, maar die offer in "divine grief" (Smail, 1987:125) laat voortgaan sodat sy Seun prysgegee word aan die dood as 'n sondaar. Smail (1987:125) praat uitdruklik van "the grief of the Father".

In ons tyd het veral Moltmann beklemtoon dat wat aan die kruis tussen Vader en Seun gebeur het, trinitaries verstaan moet word. Hy lê klem daarop dat die Vader ook gely het - nie in die tradisionele patripassianistiese sin van die woord (naamlik dat dit die Vader is wat aan die kruis gely het) nie, maar dat die Vader die dood van sy Seun ervaar het (Moltmann, 1973; 1980:96). Ons kan nie hier op Moltmann se teologie 
verder ingaan nie (vgl. F. van der Walt, 1981). Belangrike kritiek teen Moltmann is dat hy uit die oog verloor dat Christus as Middelaar gely het en verder dat hy van die kruisgebeure 'n Godsgeskiedenis maak wat as grondslag vir sy bevrydingsteologie moet dien.

Tog moet ons waardering hè vir die besondere aksent wat Moltmann gelè het. Wie onbevange luister na Johannes 3:16; Romeine 8:32 en 1 Johannes 4:9,10 kan nie aan God dink as onbewoë en apaties nie. Hier word gepraat oor God se liefdesbetrokkenheid en bewoënheid in die gee van sy Seun.

In Romeine 8:32 (in die lig van Genesis 22) word die Goddelike handeling in die oorgawe van die Seun gekwalifiseer. God se heilswerk is nie 'n onpersoonlike Goddelike bestel waaragter God self as die Onbekende verborge bly nie. Ridderbos (1959:198) sê in sy kommentaar: "God heeft in de overgawe van zijn Zoon zich als de Offerende, zichzelf schenkende laten kennen. Gods geven was niet een karig zichzelf sparend geven, maar een prijsgeven van zijn eigen en geliefde Zoon in menselijke verlorenheid. God kon niet meer en Hij kon zich niet dieper weg-schenken, dan Hij in Christus deed."

\section{DIE GAWE VAN DIE GEES}

By die gawe van die Gees by die Nagmaal dink ons dadelik aan die feit dat die Gees ons Christus en al sy weldade deelagtig maak. Christus is deur sy Gees teenwoordig by die Nagmaal en ons het gemeenskap met Hom deur sy Gees.

Maar ons moet hier ook dink aan 'n fundamentele betrokkenheid van die Gees by die selfoorgawe van die Seun. Christus het Homself "as volkome offer deur die ewige Gees aan God geoffer" (Hebr 9:14). Daar is eksegete wat oortuig is dat hier nie van die Heilige Gees sprake is nie, maar van die Goddelike natuur van Christus (Hughes, 1977:358). Volgens ander (Bruce, 1964:205; Michel, 1966:314) is hier wel sprake van die Heilige Gees en word hier iets gesê oor die Heilige Gees se betrokkenheid by Christus se offer. Calvyn sê oor hierdie vers dat Christus se dood waardeer moet word "in die krag van die Gees". Bruce dink aan die Kneg van die Here op wie die Gees van die Here kom (Jes 42:1). In die krag van die Heilige Gees volvoer die Kneg sy sending en bring Hy sy offer. Hy haal dan die woorde van Denney aan: "In Christ's sacrifice we see the final revelation of what God is, that behind which there is nothing in God, so that the religion which rests on that sacrifice rests on the ultimate truth of the divine nature, and can never be shaken" (Bruce: 205 e.v.).

Die drie-enige God géé in die selfoorgawe van die Seun. In die oorgawe van die Seun het ons met die hart van die drie-enige God te doen. Wanneer ons Nagmaal vier, gaan 
ons by die bron staan - "daar ontmoeten wij God en zien Hem in de liefde, waarmee Hij ons in zijn enige Zoon heeft liefgehad" (Trimp, 1985:99).

Dit is ook die Gees wat ons dit alles deelagtig maak: gemeenskap met Jesus Christus wat Hom vir ons oorgegee het. Calvyn sien hierdie gemeenskap in die lig van Efesiërs 3:17: "dat Christus deur die geloof in julle harte sal woon" (Calvyn, 1931:4,17,5). Dit beteken ook gemeenskap met die Vader; vergelyk Johannes 14:23 (Woelderink, 1981:77).

Dit is belangrik om daarop te let dat die gemeenskap deur die Gees gelóffsgemeenskap is. Tussen Pinkster en wederkoms kan die gemeenskap met Christus hier op aarde nie anders beleef word as deur die geloof nie. Die Nagmaal is nie 'n uitsondering hierop nie. Ook in die Nagmaal gaan dit om dieselfde gemeenskap as wat gewerk word deur die prediking (Krusche, 1957:272; Versteeg, 1980:53).

Christus se teenwoordigheid deur die Gees by die Nagmaal is dus anders as die wyse waarop Hy teenwoordig sal wees by sy wederkoms. Deur Christus se hemelvaart is 'n grens gestel aan die wyse van sy teenwonrdigheid by die Nagmaal (Berkouer, 1954: 315). Die vereniging met Christus in die Nagmaal mag innig wees, maar dit mag nie gelyk gestel word aan die vereniging wat 'n werklikheid sal word met sy wederkoms nie. Ons mag dus nie die Nagmaal sien as 'n opheffing van die skeiding wat deur die hemelvaart teweeggebring is nie. Dit is met die Nagmaal soos met die bedeling van die Gees: dit is ' $n$ onderpand, 'n vooruitbetaling op die erfenis wat ons sal ontvang (Woelderink, 1981:88). Christus se versoenende teenwoordigheid op die wyse van die Gees in die Nagmaal word verstaan as die onderpand van die uiteindelike koms van die Seun van die mens. S6 onderstreep die pneumatologie in Calvyn se sakramentsleer die verwagting van die wederkoms van Christus (Beker \& Hasselaar, 1987: 188).

Juis die gemeenskap met Christus deur die Gees laat ons met verwagting uitsien na die heerlike eskatologiese gemeenskap. Die gemeenskap wat ons nou reeds smakk, versterk ons eskatologiese verwagting en dit roep om ons antwoord, ons oorgawe.

\section{ONS OORGAWE}

Ook ons oorgawe is 'n gawe van die Gees. Daarom word in die Nagmaalsformulier gebid: "Ons bid $U$ dat $U$ deur u Ileilige Gees ' $n$ opregte vertroue in ons harte sal bewerk om ons al meer aan u Seun oor te gee ..." Die ware antwoord op Christus se selfoorgawe is ons oorgawe. Christus gee Homself aan ons; ons gee ons aan Hom, maar s6 dat ons oorgawe 'n vrug is van sy gawc (Woelderink, 1981:81).

Oorgawe is 'n saak van die hart. In Christus se selfoorgawe vir ons sien ons die 
lewende God se hart. Vader, Seun en Gees is liefdevol betrokke by hierdie geé. Daarom moet ons oorgawe met hart en siel wees. Hoe langer hoe meer. Totdat Hy kom.

\section{BIBI IOGRAFIE}

BFKER, F J \& HASSELAAR, JM 1987. Over de Heilige Gees en de sacramenten. Kampen : Kok (Wegen en kruispunten in de Dogmatiek 4)

BERKOUER, G.C. 19.54. De sacramenten. Kampen : Kok. (Dogmatische Studiēn)

BRUCE, F.F. 1964. Commeniary on the epistle to the Hebrews. London : Marshall, Morgan \& Scott. (The new London Commentary on the New Testament).

CALVYN, J. 1908. Hel evangelie van Johannes verklaard door J. Calvijn Opnieuw uit het Latijn verlaald door G.C. Goris. Kampen : Talsman

CALVYN, I. 1931. Institutie of onderwijzing in de Christelijke Godsdienst. Boek IV. Uit het Latijn verlaald door A. Sizoo. Delft : Meincma.

CLVYN, J. 1949. Commenlaries on the epistle to the Hebrews by John Calvin. Translated from the original Latin by J. Owen. Grand Rapids : Eerdmans.

HUGHES, P.E. 1977. A commenlary on the epistle to the Hebrews. Grand Rapids : Eerdmans.

KRUSCHE, W. 1957. Das Wirken des Heiligen Geistes nach Calvin. Goltingen : Van den Hoeck \& Ruprechi.

MICHEL, O. 1966. Der brief an die Hebracr. 12. Auflage 6, neubearbeitete Auflage dieser Auslegung Gollingen: Van den Hoeck \& Ruprecht

MOltmanN, J. 1973. Der gekreuzigle Gott. Das Kreuz Christi als Grund und Kritik Christlicher Theologie. Munchen: Kaiser.

MOLTMANN, J. 1980. Trinitat und Reich Goltes. Zur Golleslehre. Manchen : Kaiser

RIDDERBOS, H.N. 1959. Aan de Rameincn. Kampen : Kok. (Commentaar op het Nieuwe Testament)

SMAIL, T.A. 1987. The forgolten Father. London: Hodder \& Stoughton

TRIMP, C 1985. Wonrd, water en wijn. Gedachien over prediking, doop en avondmaal. Kampen : Kok. (Bij-Tijds Geloven)

VAN DER WALT, F. 1981 'n God wal bevry? 'n Ondersoek na die Godsleer van Jurgen Moltmann. Pouchefstromm. (Proefskrif (Th.D.) - PU vir CHO)

VERSTEEG, J.P. 1980. Het avondmaal volgens hel Nieuwe Testamen1. (In W. van 't Spijker et al. Bij brood en beker. Leer en gebruik van het heilig avondmaal in het Nieuwe Testament en in de geschicdenis van de Westerse kerk. Goudriaan : De Groot. p. 9-64).

WOELDERINK, J.G. 1981. Het pastoraal rond hel heilig auondmaal. 's Gravenhage : Boekencentrum. 